\title{
A microleakage study of gutta-percha/AH Plus and Resilon/Real self-etch systems after different irrigation protocols
}

\author{
Maíra PRADO1,2, Renata Antoun SIMÃO², Brenda Paula Figueiredo de Almeida GOMES ${ }^{1}$ \\ 1- Department of Restorative Dentistry, Endodontics Division, State University of Campinas - UNICAMP, Piracicaba, SP, Brazil. \\ 2- Department of Metallurgic and Materials Engineering, Federal University of Rio de Janeiro, Rio de Janeiro, RJ, Brazil.
}

Corresponding address: Brenda Paula F. A. Gomes - Departamento de Odontologia Restauradora, Área de Endodontia - Faculdade de Odontologia de Piracicaba - Universidade Estadual de Campinas - UNICAMP - Avenida Limeira, 901 - Piracicaba - SP - Brazil - 13414-018 - Phone: (55) $192106-5215$ - Fax: (55) 19 2106-5218 - E-mail: bpgomes@fop.unicamp.br

Submitted: April 8, 2013 - Modification: February 10, 2014 - Accepted: February 19, 2014

\section{ABSTRACT}

\begin{abstract}
$\mathrm{T}_{\mathrm{t}}^{\mathrm{h}}$ he development and maintenance of the sealing of the root canal system is the key to the success of root canal treatment. The resin-based adhesive material has the potential to reduce the microleakage of the root canal because of its adhesive properties and penetration into dentinal walls. Moreover, the irrigation protocols may have an influence on the adhesiveness of resin-based sealers to root dentin. Objective: The objective of the present study was to evaluate the effect of different irrigant protocols on coronal bacterial microleakage of gutta-percha/AH Plus and Resilon/Real Seal Self-Etch systems. Material and Methods: One hundred ninety pre-molars were used. The teeth were divided into 18 experimental groups according to the irrigation protocols and filling materials used. The protocols used were: distilled water; sodium hypochlorite $(\mathrm{NaOCl})+\mathrm{EDTA} ; \mathrm{NaOCl}+\mathrm{H}_{3} \mathrm{PO}_{4}$; $\mathrm{NaOCl}+\mathrm{EDTA}+$ chlorhexidine $(\mathrm{CHX}) ; \mathrm{NaOCl}+\mathrm{H}_{3} \mathrm{PO}_{4}+\mathrm{CHX} ; \mathrm{CHX}+\mathrm{EDTA} ; \mathrm{CHX}+\mathrm{H}_{3} \mathrm{PO}_{4}$; $\mathrm{CHX}+\mathrm{EDTA}+\mathrm{CHX}$ and $\mathrm{CHX}+\mathrm{H}_{3} \mathrm{PO}_{4}+\mathrm{CHX}$. Gutta-percha/AH Plus or Resilon/Real Seal SE were used as root-filling materials. The coronal microleakage was evaluated for 90 days against Enterococcus faecalis. Data were statistically analyzed using Kaplan-Meier survival test, Kruskal-Wallis and Mann-Whitney tests. Results: No significant difference was verified in the groups using chlorhexidine or sodium hypochlorite during the chemo-mechanical preparation followed by EDTA or phosphoric acid for smear layer removal. The same results were found for filling materials. However, the statistical analyses revealed that a final flush with $2 \%$ chlorhexidine reduced significantly the coronal microleakage. Conclusion: A final flush with $2 \%$ chlorhexidine after smear layer removal reduces coronal microleakage of teeth filled with gutta-percha/AH Plus or Resilon/Real Seal SE.
\end{abstract}

Keywords: Chlorhexidine. Dental leakage. Root canal irrigants. Root canal obturation.

\section{INTRODUCTION}

The major aim of root canal therapy is to prevent and treat periradicular inflammation by eliminating microorganisms from the root canal system. The methods commonly used for this purpose include root canal preparation using different instruments and irrigants, adequate filling, and coronal restoration ${ }^{1,14}$

Chemical irrigants are essential for successful debridement of root canals during cleaning and shaping procedures ${ }^{11}$. They are used during chemo- mechanical procedures not only as antimicrobial agents, but also to lubricate the dentinal walls, flush out debris and dissolve organic and inorganic components of the smear layer, thus cleaning the dentin surface ${ }^{2,17}$. Different irrigants have been proposed and used, including: $5.25 \%$ sodium hypochlorite, $2 \%$ chlorhexidine, 17\% EDTA, 10\% citric acid and $37 \%$ phosphoric acid solution ${ }^{17,18,20}$.

Chlorhexidine has been used as irrigant during root canal therapy because of its antibacterial effects, substantivity, and relative absence of cytotoxicity, even though this solution is unable 
to dissolve the tissue. Additionally, chlorhexidine has been suggested as a final irrigant ${ }^{30}$. Regarding its use as final irrigant, a final flush with $2 \%$ chlorhexidine favors the wettability of $\mathrm{AH}$ Plus and Real Seal SE sealers on the dentin surface. Furthermore, it was verified that the bond strength of ActiV GP, a glass ionomer based system, was improved by using $2 \%$ chlorhexidine in the final irrigation after $17 \%$ EDTA.

The development and maintenance of the sealing of the root canal system is the key to the success of root-canal treatment. The resin-based adhesive material has the potential to reduce the microleakage of the root canal because of its adhesive properties and penetration into dentinal walls ${ }^{25}$. Moreover, the irrigation protocols may have an influence on the adhesiveness of resin-based sealers to root dentin ${ }^{8}$.

A variety of experimental models are used to detect and measure any leakage along endodontic fillings, such as dye penetration, clearing of the teeth, radioisotope tests, bacterial penetration, electrochemical tests, fluid filtration, and glucose penetration model ${ }^{12,24}$.

The aim of the present study was to evaluate the effect of different irrigant protocols on coronal bacterial microleakage of gutta-percha/AH Plus and Resilon/Real Seal Self-Etch systems.

\section{MATERIAL AND METHODS}

\section{Sample preparation}

One hundred ninety single-rooted pre-molars with straight roots, mature root apices and similar anatomical characteristics were used in this study. All instruments used in the root canal preparation were sterilized previously to the procedure. The teeth were positioned on a metallic apparatus that allowed for all procedures to be carried out without manual contact with the roots. Conventional access was performed using high-speed diamond burs. A size 10 K-file (Dentsply Maillefer, Petrópolis, Rio de Janeiro, Brazil) was used to verify the patency of the canals and to determine the total length of the root canal, i.e. the work length. This was observed when the instrument reached the apical foramen. Next, the foramina were standardized by using a size $20 \mathrm{~K}$-file and root canals were shaped by using MTwo NiTi rotary system (VDW, Münich, Bavaria, Germany). The sequence employed was the following: 10/.04, 15/.05, 20/.06, 25/.06, $30 / .05,35 / .04,40 / .04$, and 25/.07. The teeth were divided into groups of ten according to the irrigation regimen (Figure 1 ) and root canal filling.

Before the insertion of each file, $2 \%$ chlorhexidine (CHX) gel (Drogal, Piracicaba, São Paulo, Brazil) or $5.25 \%$ sodium hypochlorite $(\mathrm{NaOCl})$ (Drogal, Piracicaba, São Paulo, Brazil) were used as chemical-auxiliary substance. Once the preparation was finished, $10 \mathrm{~mL}$ of distilled water (DW) was used to remove the chemical-auxiliary substance.

\begin{tabular}{|c|c|c|c|c|}
\hline Groups & $\begin{array}{c}\text { Chemical-auxiliary } \\
\text { substance }\end{array}$ & Intermediate flush & Smear layer removal & Final flush \\
\hline Distilled water (DW) & $6 \mathrm{~mL}$ DW & $10 \mathrm{~mL} \mathrm{DW}$ & $3 \mathrm{~mL}$ DW & $10 \mathrm{~mL} \mathrm{DW}$ \\
\hline $\mathrm{NaOCl} / \mathrm{EDTA}$ & $\begin{array}{c}1 \mathrm{~mL} 5.25 \% \mathrm{NaOCl}+ \\
5 \mathrm{~mL} \mathrm{DW}\end{array}$ & $10 \mathrm{~mL} \mathrm{DW}$ & $3 \mathrm{~mL}$ 17\% EDTA & $10 \mathrm{~mL} \mathrm{DW}$ \\
\hline $\mathrm{NaOCl} / \mathrm{H}_{3} \mathrm{PO}_{4}$ & $\begin{array}{c}1 \mathrm{~mL} 5.25 \% \mathrm{NaOCl}+ \\
5 \mathrm{~mL} \mathrm{DW}\end{array}$ & $10 \mathrm{~mL} \mathrm{DW}$ & $\begin{array}{c}3 \mathrm{~mL} 37 \% \text { phosphoric } \\
\text { acid }\end{array}$ & $10 \mathrm{~mL} \mathrm{DW}$ \\
\hline $\mathrm{NaOCI} / \mathrm{EDTA} / \mathrm{CHX}$ & $\begin{array}{c}1 \mathrm{~mL} 5.25 \% \mathrm{NaOCl}+ \\
5 \mathrm{~mL} \mathrm{DW}\end{array}$ & $10 \mathrm{~mL} \mathrm{DW}$ & $3 \mathrm{~mL}$ 17\% EDTA & $\begin{array}{c}5 \mathrm{~mL} \text { DW }+5 \mathrm{~mL} 2 \% \\
\mathrm{CHX} \text { solution }\end{array}$ \\
\hline $\mathrm{NaOCl} / \mathrm{H}_{3} \mathrm{PO}_{4} / \mathrm{CHX}$ & $\begin{array}{c}1 \mathrm{~mL} 5.25 \% \mathrm{NaOCl}+ \\
5 \mathrm{~mL} \mathrm{DW}\end{array}$ & $10 \mathrm{~mL} \mathrm{DW}$ & $\begin{array}{c}3 \mathrm{~mL} 37 \% \text { phosphoric } \\
\text { acid }\end{array}$ & $\begin{array}{c}5 \mathrm{~mL} \text { DW }+5 \mathrm{~mL} 2 \% \\
\mathrm{CHX} \text { solution }\end{array}$ \\
\hline CHX/EDTA & $\begin{array}{c}1 \mathrm{~mL} 2 \% \mathrm{CHX} \text { gel }+5 \\
\mathrm{~mL} \mathrm{DW}\end{array}$ & $10 \mathrm{~mL} \mathrm{DW}$ & $3 \mathrm{~mL}$ 17\% EDTA & $10 \mathrm{~mL} \mathrm{DW}$ \\
\hline $\mathrm{CHX} / \mathrm{H}_{3} \mathrm{PO}_{4}$ & $\begin{array}{c}1 \mathrm{~mL} 2 \% \text { CHX gel }+5 \\
\text { mL DW }\end{array}$ & $10 \mathrm{~mL} \mathrm{DW}$ & $\begin{array}{c}3 \mathrm{~mL} 37 \% \text { phosphoric } \\
\text { acid }\end{array}$ & $10 \mathrm{~mL} \mathrm{DW}$ \\
\hline CHX/EDTA/CHX & $\begin{array}{c}1 \mathrm{~mL} 2 \% \mathrm{CHX} \text { gel }+5 \\
\mathrm{~mL} \mathrm{DW}\end{array}$ & $10 \mathrm{~mL} \mathrm{DW}$ & $3 \mathrm{~mL}$ 17\% EDTA & $\begin{array}{c}5 \mathrm{~mL} \text { DW }+5 \mathrm{~mL} 2 \% \\
\mathrm{CHX} \text { solution }\end{array}$ \\
\hline $\mathrm{CHX} / \mathrm{H}_{3} \mathrm{PO}_{4} / \mathrm{CHX}$ & $\begin{array}{c}1 \mathrm{~mL} 2 \% \mathrm{CHX} \text { gel }+5 \\
\mathrm{~mL} \mathrm{DW}\end{array}$ & $10 \mathrm{~mL} \mathrm{DW}$ & $\begin{array}{c}3 \mathrm{~mL} 37 \% \text { phosphoric } \\
\text { acid }\end{array}$ & $\begin{array}{c}5 \mathrm{~mL} \text { DW }+5 \mathrm{~mL} 2 \% \\
\mathrm{CHX} \text { solution }\end{array}$ \\
\hline
\end{tabular}

${ }^{*} \mathrm{CHX}$ - chlorhexidine

Figure 1- Protocols for irrigation 
Next, $17 \%$ EDTA or $37 \%$ phosphoric acid solution (Drogal, Piracicaba, São Paulo, Brazil) was used for 3 minutes to remove the smear layer, with changes every 1 minute ( $1 \mathrm{~mL}$ per minute). Again, DW was used to remove the remaining solution. Finally, 2\% chlorhexidine solution (Drogal, Piracicaba, São Paulo, Brazil) was used for final flush. During the chemo-mechanical preparation, all teeth had their apices sealed with utility wax (Technew, Rio de Janeiro, Rio de Janeiro, Brazil) to prevent flow through them.

The root canals were dried with sterilized medium-sized paper points (Endopoints, Paraíba do Sul, Rio de Janeiro, Brazil). Groups 1 to 9 had the canals filled with gutta-percha cones (Odous, Belo Horizonte, Minas Gerais, Brazil) associated with AH Plus sealer (Dentsply, Petrópolis, Rio de Janeiro, Brazil), whereas Groups 10 to 18 had the canals filled with Resilon associated with Real Seal SE (SybronEndo, Orange, California, USA). The cones packages were opened and they were used immediately, and the sealers were manipulated in sterile plates according to the manufacturer's recommendations.

A System-B endodontic heat source unit (SybronEndo, Orange, California, USA) was used to down-pack and Obtura System (J Morita, São Paulo, São Paulo, Brazil) to backfill. All procedures were conducted at the laminar flow cabinet. Subsequently, teeth were radiographed mesiodistally and buccolingually to assess the quality of the filling.

All roots were kept on gauzes at $37^{\circ} \mathrm{C}$ and $100 \%$ humidity for 2 weeks before leakage measurement in order to allow the materials to set properly.

Next, the external root surface of all specimens was sealed with two layers of red nail varnish (Revlon, New York, New York, USA), except the last
$1 \mathrm{~mm}$ of the apex.

Analysis of coronal bacterial microleakage

Figure 2a illustrates the apparatus used to evaluate coronal leakage ${ }^{10}$. Glass vials with rubber stoppers were adjusted for use. By using a shear, a hole was made at the center of each rubber stopper (Figure 2b), through which each tooth was inserted under pressure up to the cementoenamel junction, so that its crown was outside the vial and its root inside (Figure 2c). Cyanoacrylate glue (CG) was applied at the interface between tooth and stopper for sealing ${ }^{15}$. Cylinders prepared from $10 \mathrm{~mL}$ plastic syringes were adapted to the outer surface of the stoppers to create a chamber around the crown of the tooth (Figure 2d). Again, CG was used at the interface between syringes and stoppers, followed by a Parafilm layer (American National CanTM, Menasha, Wisconsin, USA) to help in the sealing. The syringe/stopper/tooth sets were submitted to sterilization by gamma-rays (Embrarad, São Paulo, São Paulo, Brazil). The glass flasks were autoclaved at $121^{\circ} \mathrm{C}$ for 15 minutes.

The sterilized glass flasks were then filled with sterile Brain Heart Infusion broth (BHI; Oxoid, São Paulo, São Paulo, Brazil) so that a 2-mm length of root apex was immersed in the broth. CG and Parafilm were used to seal the interface between stopper and flask (Figure 2e). In all samples, in order to ensure the efficiency of the seal, $2 \mathrm{~mL}$ of $1 \%$ sterile methylene blue dye was placed into the tube until the coronal portion of the sample was reached ${ }^{15}$. The flasks were then incubated at $37^{\circ} \mathrm{C}$ for 3 days to ensure sterilization. After the third day, the methylene blue was removed with sterile distilled water by using a pipette. When a green medium was observed the specimen was discarded. The green color was due to the blue dye association

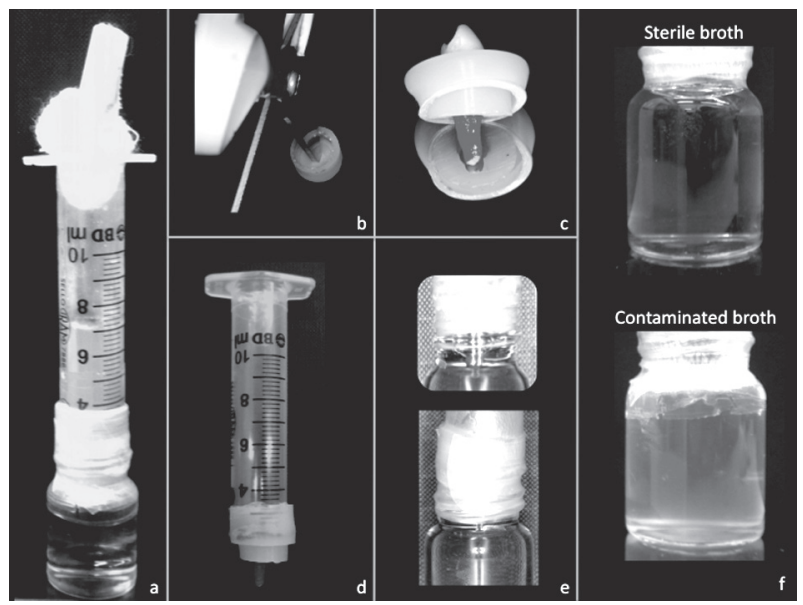

Figure 2- The apparatus used to evaluate coronal leakage (a). By using a shear, a hole was made at the center of the rubber stopper (b), through which the tooth was inserted (c). A cylinder prepared from a $10 \mathrm{~mL}$ plastic syringe was adapted to the outer surface of the stopper to create a chamber around the crown of the tooth (d). The glass flask filled with $\mathrm{BHI}$ broth was connected to the syringe/stopper/tooth set (e). Turbidity in the BHI broth was evaluated (f) 


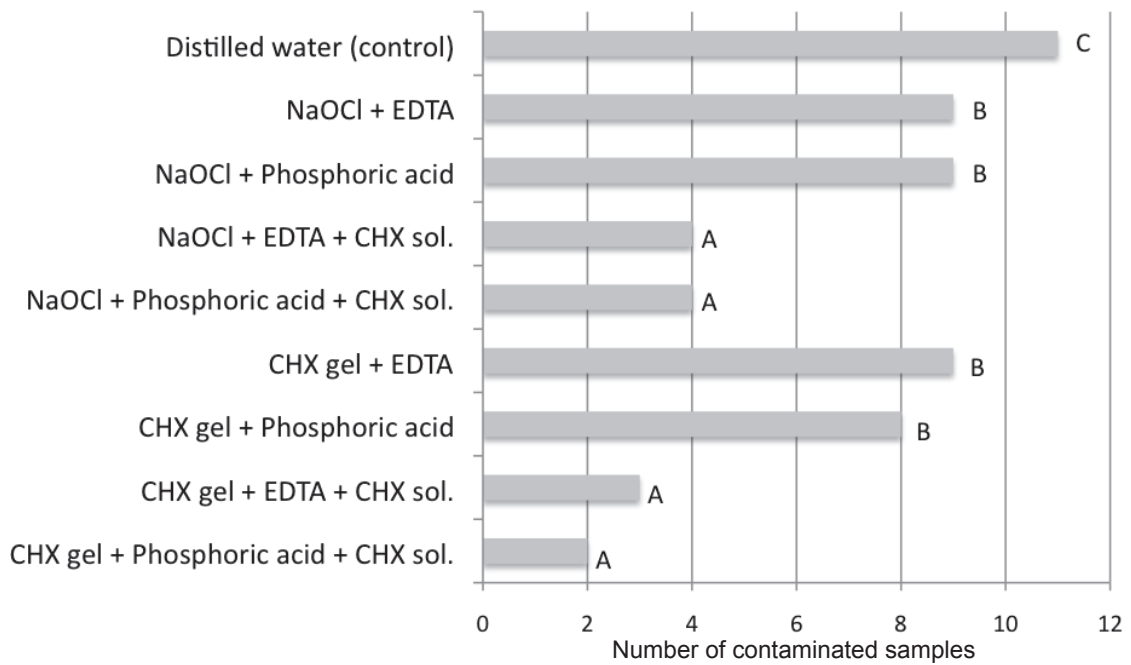

*Different letters indicate statistically significant values $(P<0.05)$

Figure 3- Graph showing the number of contaminated samples according to the irrigation protocol

with the yellow medium.

For preparation of microbial medium ${ }^{28}$, Enterococcus faecalis (ATCC 29212) was grown on BHI agar plates (Brain Heart Infusion agar; Oxoid, São Paulo, São Paulo, Brazil) and supplemented with $5 \%$ sheep blood for 24 hours at $37^{\circ} \mathrm{C}$ in $\mathrm{CO}_{2}$. Then, the Enterococcus faecalis was inoculated into tubes containing $5 \mathrm{~mL}$ sterile BHI suspension, which were adjusted spectrophotometrically at $800 \mathrm{~nm}$ (OD800) to a turbidity of $1.5 \times 10^{8}$ colony-forming units (CFU)/mL. With the aid of a pipette, $5 \mathrm{~mL}$ of the suspensions were placed into the syringe apparatuses (in the upper region, removing the gauze stop), which were left at $37^{\circ} \mathrm{C}$ for 90 days in $\mathrm{CO}_{2}$ and checked daily for turbidity in the $\mathrm{BHI}$ broth. When turbidity (Figure $2 \mathrm{f}$ ) was observed, the day was recorded.

Every 2 days, $3 \mathrm{~mL}$ of the suspension (BHI+microorganisms) were removed from the chamber and replaced by $3 \mathrm{~mL}$ of $\mathrm{BHI}$ to avoid saturation and to confirm the growth of Enterococcus faecalis ${ }^{5}$.

After this period, all apparatuses were opened to evaluate the sterile hood. Positive cultures were confirmed by using Gram staining (gram-positive), colony morphology on blood agar plates (cocci) and biochemical identification kits (Rapid ID 32 Strep, BioMérieux SA, Marcyl'Etoile, Charbonnieres-lesBains, France).

Ten samples were used as positive $(n=5)$ and negative $(n=5)$ controls. The positive controls consisted of instrumented teeth without obturation, while negative controls consisted of sound teeth, both with no contamination.

The results were analyzed with Kaplan-Meier survival test, Kruskal-Wallis and Mann-Whitney tests $(p<0.05)$.

\section{RESULTS}

No differences were found following the use of chlorhexidine or $\mathrm{NaOCl}$ associated with EDTA or phosphoric acid for smear layer removal. However, it was clearly observed that groups receiving a final flush with chlorhexidine showed a lower number of contaminated samples.

Figure 3 shows the number of contaminated samples according to the irrigation protocol.

Regarding the root canal filling system (guttapercha/AH Plus and Resilon/Real Seal SE), there was no statistically significant differences in relation to the coronal microleakage.

Figure 4 shows the number of contaminated samples in relation to time. Statistic analysis of the contamination days revealed difference in the groups receiving the final flush with chlorhexidine. Chlorhexidine groups started to contaminate only in the $6^{\text {th }}$ week, while in the others the microbial growth was verified in the $1^{\text {st }}$ or $2^{\text {nd }}$ week. The control apparatuses showed broth turbidity within 1 day of incubation in all samples, whereas no microbial growth was found in the negative control throughout the experiment.

\section{DISCUSSION}

Leakage of the root canal has been defined as the passage of bacteria, fluids, and chemical substances between the dentinal wall and the root canal filling material, and results from the presence of space at the interface of the filling material and the root canal wall. This space can result from deficient adaptation of the filling material to the root dentin, solubility of the sealer, or sealer expansion or shrinkage. There are 2 possibilities of leakage: at the interface between the main filling material and sealer, or between the sealer and root canal wall ${ }^{26}$. 


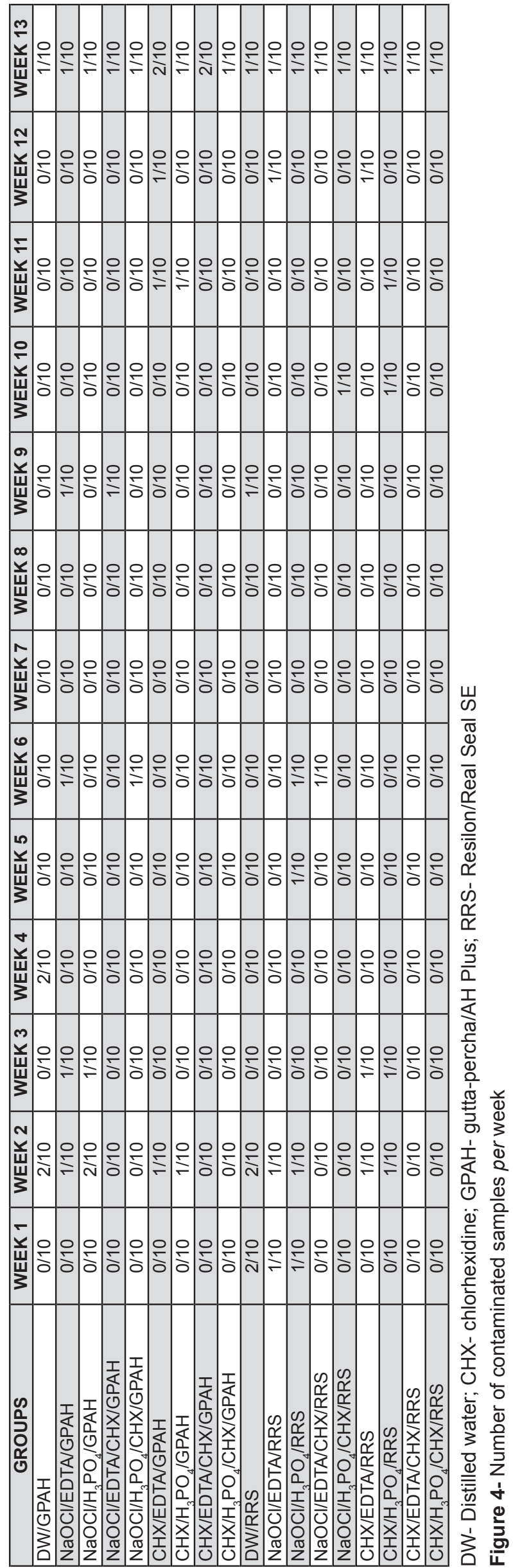

In the present study, the coronal bacterial microleakage was used. This methodology is reproducible and has clinical relevance, presenting reliable data and simulating clinical conditions $\mathrm{s}^{7,13,16}$. This methodology allows the observation of the exact day of the sample contamination, showed by the broth turbidity.

The $37 \%$ phosphoric acid was evaluated in comparison with EDTA because this solution is effective for smear layer removal, showing better results than EDTA in the apical third during 3 minutes ${ }^{19}$. Additionally, the protocols associating $\mathrm{NaOCl}$ with phosphoric acid showed higher bond strength values when compared with $\mathrm{NaOCl}$ associated with EDTA ${ }^{20}$. Although phosphoric acid had showed better performance in removing the smear layer from the apical third ${ }^{19}$, it did not influence the results of coronal leakage.

The $2 \%$ chlorhexidine, a cationic bisbiguanide, was used here for the final flush after smear layer removal. This substance has a broad-spectrum MMP-inhibitory effect that improves the integrity of the hybrid layer ${ }^{6}$ and the resin-dentin bond stability ${ }^{23}$. Additionally, the use of $\mathrm{CHX}$ increases the wettability of endodontic sealers on dentin ${ }^{3}$, which can be explained by the presence of surface surfactant in $\mathrm{CHX}$, increasing the surface energy and promoting higher wetting ability to dentin. Our results showed that a final flush with chlorhexidine significantly reduced the coronal microleakage, when compared to the other experimental groups. It might be explained by the fact that chlorhexidine is adsorbed onto dentin and prevent microbial colonization ${ }^{21}$, increasing the time required for recontamination of filled root $^{23}$ up to 12 weeks due to its substantivity ${ }^{21}$.

Regarding the effect of a final flush with chlorhexidine on adhesion, previous studies showed that this solution did not affect the bond strength of resin-based sealers ${ }^{17,20}$ and improved the adhesion of hydrophilic bonded materials such as ActiV GP and Epiphany ${ }^{23}$.

$\mathrm{NaOCl}$ was not used as a final irrigant because a previous study showed that this solution decreased the bond strength between epoxy resin and dentin and increased the leakage ${ }^{17}$.

Regarding the root canal filling system (guttapercha/AH Plus and Resilon/ Real Seal SE), there was no statistically significant differences in relation to the coronal microleakage, agreeing with previous findings $s^{4,9,26}$. However, some studies reported that Resilon/Epiphany sealer was more efficient than gutta-percha/AH Plus ${ }^{12,29}$, whereas others found the opposite 22,27 . 


\section{CONCLUSION}

In conclusion, a final flush with $2 \%$ chlorhexidine after smear layer removal reduces coronal microleakage of teeth filled with gutta-percha/AH Plus or Resilon/Real Seal Self-Etch. The bacterial leakage methodology used made possible the verification of this behavior.

\section{ACKNOWLEDGEMENTS}

This work was supported by the Brazilian agencies FAPESP - São Paulo Research Foundation (2009/53976-0; 2010/50817-5), CAPES Coordination for the Improvement of Higher Education Personnel, and CNPq - National Council for Scientific and Technological Development (302575/2009-0).

\section{REFERENCES}

1- Adamo HL, Buruiana R, Schertzer L, Boylan RJ. A comparison of MTA, Super EBA, composite and amalgam as root end filling materials using a bacterial microleakage model. Int Endod $\mathrm{J}$. 1999;32:197-203.

2- Akisue E, Tomita VS, Gavini G, Poli de Figueiredo JA. Effect of the combination of sodium hypochlorite and chlorhexidine on dentinal permeability and scanning electron microscopy precipitate observation. J Endod. 2010;36:847-50.

3- Assis DF, Prado M, Simão RA. Evaluation of the interaction between endodontic sealers and dentin treated with different irrigant solutions. J Endod. 2011;37:1550-2.

4- Baumgartner G, Zehnder M, Paqué F. Enterococcus faecalis type strain leakage through root canals filled with Gutta-Percha/ AH Plus or Resilon/Epiphany. J Endod. 2007;33:45-7.

5- Berber VB, Gomes BP, Sena NT, Vianna ME, Ferraz CC, Zaia $A A$, et al. Efficacy of various concentrations of $\mathrm{NaOCl}$ and instrumentation techniques in reducing Enterococcus faecalis within root canals and dentinal tubules. Int Endod J. 2006;39:10-7. 6- Carrilho MR, Carvalho RM, Goes MF, di Hipólito V, Geraldeli S, Tay FR, et al. Chlorhexidine preserves dentin bond in vitro. J Dent Res. 2007;86:90-4.

7- Chailertvanitkul P, Saunders WP, MacKenzie D. Coronal leakage of obturated root canals after long-term storage using a polymicrobial marker. J Endod. 1997;23:610-3.

8- De-Deus G, Namen F, Galan J Jr, Zehnder M. Soft chelating irrigation protocol optimizes bonding quality of Resilon/Epiphany root fillings. J Endod. 2008;34:703-5.

9- Fransen JN, He J, Glickman GN, Rios A, Shulman JD, Honeyman A. Comparative assessment of ActiV GP/glass ionomer sealer, Resilon/Epiphany, and gutta-percha/AH plus obturation: a bacterial leakage study. J Endod. 2008;34:725-7.

10- Gomes BP, Sato E, Ferraz CC, Teixeira FB, Zaia AA, Souza-Filho FJ. Evaluation of time required for recontamination of coronally sealed canals medicated with calcium hydroxide and chlorhexidine. Int Endod J. 2003;36:604-9.

11- Hashem AA, Ghoneim AG, Lutfy RA, Fouda MY. The effect of different irrigating solutions on bond strength of two root canalfilling systems. J Endod. 2009;35:537-40.

12- Hirai VH, Silva Neto UX, Westphalen VP, Perin CP, Carneiro E, Fariniuk LF. Comparative analysis of leakage in root canal fillings performed with gutta-percha and Resilon cones with AH Plus and Epiphany sealers. Oral Surg Oral Med Oral Pathol Oral Radiol Endod. 2010;109:e131-5.
13- Imura N, Otani SM, Campos MJ, Jardim Júnior EG, Zuolo ML. Bacterial penetration through temporary restorative materials in root-canal-treated teeth in vitro. Int Endod J. 1997;23:1-5.

14- Jacobovitz M, Vianna ME, Pandolfelli VC, Oliveira IR, Rossetto $\mathrm{HL}$, Gomes BP. Root canal filling with cements based on mineral aggregates: an in vitro analysis of bacterial microleakage. Oral Surg Oral Med Oral Pathol Oral Radiol Endod. 2009;108:140-4. 15- Malone $\mathrm{KH} 3^{\text {rd }}$, Donnelly JC. In vitro evaluation of coronal microleakage in obturated root canals without restorations. J Endod. 1997;23:35-8.

16- Nair U, Ghattas S, Saber M, Natera M, Walker C, Pileggi R. A comparative evaluation of the sealing ability of 2 root-end filling materials: an in vitro leakage study using Enterococcus faecalis. Oral Surg Oral Med Oral Pathol Oral Radiol Endod. 2011;112:e74-7. 17- Neelakantan P, Subbarao C, Subbarao CV, De-Deus G, Zehnder $M$. The impact of root dentine conditioning on sealing ability and push-out bond strength of an epoxy resin root canal sealer. Int Endod J. 2011;44:491-8

18- Park DS, Torabinejad M, Shabahang S. The effect of MTAD on the coronal leakage of obturated root canals. J Endod. 2004;30:890-2.

19- Prado M, Gusman H, Gomes BP, Simão RA. Scanning electron microscopic investigation of the effectiveness of phosphoric acid in smear layer removal when compared with EDTA and citric acid. J Endod. 2011;37:255-8.

20- Prado M, Simão RA, Gomes BP. Effect of different irrigation protocols on resin sealer bond strength to dentin. J Endod. 2013;39:689-92.

21- Rosenthal S, Spångberg L, Safavi K. Chlorhexidine substantivity in root canal dentin. Oral Surg Oral Med Oral Pathol Oral Radiol Endod. 2004;98:488-92.

22- Saleh IM, Ruyter IE, Haapasalo M, Ørstavik D. Bacterial penetration along different root canal filling materials in the presence or absence of smear layer. Int Endod J. 2008;41:32-40. 23- Sharifian MR, Shokouhinejad N, Aligholi M, Jafari Z. Effect of chlorhexidine on coronal microleakage from root canals obturated with Resilon/Epiphany Self-Etch. J Oral Sci. 2010;52:83-7.

24- Shemesh H, Wu MK, Wesselink PR. Leakage along apical root fillings with and without smear layer using two different leakage models: a two-month longitudinal ex vivo study. Int Endod J. 2006;39:968-76.

25- Shipper G, Ørstavik D, Teixeira FB, Trope M. An evaluation of microbial leakage in roots filled with a thermoplastic synthetic polymer-based root canal filling material (Resilon). J Endod 2004;30:342-7.

26- Shokouhinejad N, Sharifian MR, Aligholi M, Assadian H, Tabor RK, Nekoofar MH. The sealing ability of resilon and gutta-parcha following different smear layer removal methods: an ex vivo study. Oral Surg Oral Med Oral Pathol Oral Radiol Endod. 2010;110:e45-9. 27- Stratton RK, Apicella MJ, Mines P. A fluid filtration comparison of gutta-percha versus Resilon, a new soft resin endodontic obturation system. J Endod. 2006;32:642-5.

28- Vianna ME, Gomes BP, Sena NT, Zaia AA, Ferraz CCRF, SouzaFilho FJ. In vitro evaluation of the susceptibility of endodontic pathogens to calcium hydroxide combined with different vehicles. Braz Dent J. 2005;16:175-80.

29- Wedding JR, Brown CE, Legan JJ, Moore BK, Vail MM. An in vitro comparison of microleakage between Resilon and guttapercha with a fluid filtration model. J Endod. 2007;33:1447-9. 30- Zehnder M. Root canal irrigants. J Endod. 2006;32:389-98. 